\title{
The Effect of Human Capital Investment on Customer Satisfaction
}

\author{
${ }^{1}$ Faisal Mehmood, ${ }^{2}$ Madam Sana Iqbal \\ ${ }^{1,2}$ Foundation University Institute of Engineering \& Management Sciences, New Lalazar, Rawalpindi Cantt. \\ Pakistan.
}

\begin{abstract}
In this study the researcher worked on the relationship of human capital investment on customer satisfaction. The mediating variable employee performance is also included in the study which gives the positive and significant results. The results are concluded by applying the regression analysis in three steps. The primary data is collected by using questionnaires and sample size was 345. Hence the results accepted the entire hypothesis and there is significant relationship between human capital investment and customer satisfaction.
\end{abstract}

Keywords: Human capital investment, Customer satisfaction, Employee performance.

\section{Introduction}

Human capital is considered the assets of the organization. The worth of human capital is determined by various factors as the personal attitude and the talent, his behavior toward the life and business, old experiences and most importantly education (Hudson 1993). From the organizational point of view the capabilities he possessed is knowledge, skills and his ability to perform work matters as human capital (Hitt et al. 2001). The company's profitability and earnings mainly depend upon the level of its human capital (Young 2006). How they utilized their human capital at all level of organization and get the benefit. In today's business world, the firm's quality and worth is determined by the efficient human capital they possess. They are considered at excellence if they having the best and quality human capital (Schlesinger and Zornitsky 1991). The credit of having the best human capital in any organization is goes to the employers as the manage them.

The customer satisfaction is the ultimate goal of any organization. The satisfied customer gives the profit to the business. The customer satisfaction is highly depends upon the employees attitude and the service quality offered to him. Many researchers including Hartline and Ferrell, (1996) agree that by enhancing the service quality by inducing better human capital, one can enhanced the customer satisfaction.

The relationship between the customers satisfactions due to human capital is understood (Fornell et al. 2006). But the question to investigate is how the satisfied customer's impacts the human capital. From many studies including (Anderson, Fornell, and Mazvancheryl 2004) shows that the customer satisfaction can impact on the organization's future human capital performance. There are many factors which strengthen this relationship (Jurgensen 1978). One of them is the relationship between the financial performance and the customer satisfaction. When the customer is satisfied, it enhanced the profitability of the organization and the ultimate beneficiary will be human capital of the organization (Ping 1993). To retain the employees, business provides the financial rewards to the employees, which gives satisfaction to the employees.

Here the impact of signaling theory is implied as the satisfied customer of any organization contributes in an organizational attractiveness. According to the Harter, Hayes, and Schmidt's (2002)) company's future cash flows and profitability growth is enhanced with the customer satisfaction. The profitability and smooth earnings also affect the employees and competent human capital performance also enhance.

The customer satisfaction on the human capital will give its signaling effect when this information is float in the market. The media coverage and surveys circulated in the market the news of customer satisfaction rate of any organization (Young 2006). This promotion enhances the firm's attractiveness and qualified employees approach the firm. They can demand high salaries and for better future career from the employers as they will retain the firm's position.

According to the theory of emotional contagion given by Pugh (2001) holds that exposure to a person who expresses positive or negative emotions can produce a corresponding change in the observer's emotional state. A satisfied employees dealing with the customer have more impact than dealing of non satisfied employees. In many businesses customer satisfaction is achieved by the interaction of employees and customers. Here the human capital relation with satisfied customer is more enhanced. Empirically, Ryan, Schmit, and Johnson (1996) find that consumer satisfaction has a positive impact on employee satisfaction over time. So it's obvious the companies having more customer loyalty, they attract the competent employees as well. 
The significance of the study is also that it helps in understanding the relationship of human capital performance with the customer satisfaction. It gives the direction to the managers to understand the different aspects of the employee's behavior with the satisfied customer.

\section{Literature Review}

It is established by numerous researcher that customer satisfaction is an innermost in marketing research. The famous paper of Keiningham, Munn, and Evans (2003), concluded in his paper that "both practitioners and academics have accepted the premise that customer satisfaction results in customer behavior patterns that positively affect business results." The study who strengthen this argument is done by Seiders and colleagues (2005) stated that the reprahase and loyalty of the customer are dependent on the customer satisfaction, which is the most significant aspect of marketing. Furthermore, Szymanski and Henard (2001) argue that customer satisfaction is the integral part of customer-oriented business practices carried on by any sort of business.

Mittal and Kamakura (2001) suggests that gaining customer satisfaction is the strategic goal for the business to achieve. This topic grasps the attention of the researcher since long. It is accepted that customer satisfaction is essential for the smooth running of the business (Oliver 1980; Fornell et al. 2006; Luo; 2006) and other researchers have examined theoretical and conceptual underpinnings of customer satisfaction (Rust et al. 2004).

Many worker carried on research on the multiple outcomes of the customer satisfaction. (e.g., Oliver 1980). The of the main outcome is its impact on the human capital investigated by many researcher and concluded the positive relation (Reichheld and Sasser, 1990). Anderson, Fornell, and Rust (1997) also show that customer satisfaction optimistically affects the ratio of sales to employee. Rust, Moorman, and Dickson (2002) proved the relationship of customer satisfaction with the financial performance of the firm which benefit also goes to the human capital. This is visible by the fact that the satisfied customer repurchase or remain loyal to the firm, this enhance the earnings of the organization, as with the increase in the horizon of customer satisfaction its market share will increase. The firms having smooth market share will earn more profitably and competent human capital starts attracting towards it. Mittal and colleagues (2005) and Rust, Moorman, and Dickson (2002) also concluded that the customer satisfaction has the impact on the different outcomes. If we talk about the theory then the human resources theory suggests that being an attractive employer with better human capital is a key success factor for firms (Becker, 1964). The firms with higher customer satisfaction is liked in the market as well as famous so they have more attractive employers and thus can often hire better people (as they give positive signal financial success); as a result, such firms are able to enjoy superior human capital performance (e.g., Dess and Shaw 2001). All organizations are willing to acquire the best employees from the market so to have the "star" employees (e.g., Fortune 2006). They understand they worth of human capital in the organization.

Ryan, Schmit, and Johnson (1996) work on the relationship of customer satisfaction and employee satisfaction and also prove it as significant and positive. Before their research no previous research were found on the same variables.

To study the impact of customer satisfaction on the human capital it's important to have a methodology. From a methodological point of view, the current study has two distinctive features. First, it is based entirely on secondary data merged from different archival sources. Second, it offers a dynamic analysis in a longitudinal design. Before presenting the data and the results, we develop the underlying hypothesis.

H1: Human Capital investment is directly related with the Customer satisfaction.

H2: Human Capital investment is directly related with the employee performance.

H3: Employee performance is directly related with the customer satisfaction.

H4: Employee performance mediates the relationship between human capital investment and customer satisfaction.

\section{Theoretical Framework}

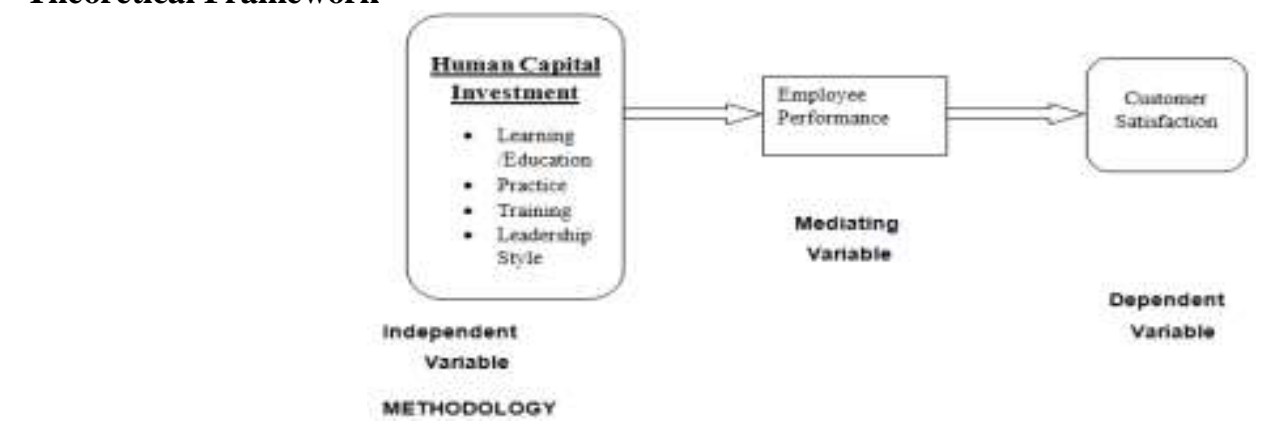




\section{Data Collection}

\section{Methodology}

Questionnaire survey method was used for data collection. To measure Human capital Investment, the tool was adopted from the work of Black and Lynch (1996). The questionnaire related to the employee performance and customer satisfaction was adopted from the work of Salanova \& Peiro (2005) and Peterson \& William (1992). The regression analysis was applied to measure the relationship between all the variables. The mediation four steps by Baron and Kenny (1986) were applied to check the mediating role of employee performance.

\section{Sample of the Study}

The Banking sector of Pakistan is the population of the study. It was selected because they have strong human capital investment and large customer base in Pakistan. The sample of the banks was base on only the government sector bank National bank of Pakistan, and the other private sectors banks as Habib bank limited, Muslim commercial bank, the famous Standard Chartered Bank and the Bank Alfalah. Research was conducted in the cities of Islamabad and Rawalpindi. The sample size of the research was decided on the basis of researcher convenience. Multiple employees working in the bank were the respondents so that the entire prospectus of the study was captured. Total 400 questionnaires were distributed for data collection and convenience sampling is considered because to acquire the reasonable response rate. Out of 400, total 360 questionnaires were collected back in which 345 were completely and properly filled. So the respond rate was $86 \%$.

\section{Results and Analysis}

For the complete analysis the mediate multiple regression models are used in this research paper. The results calculated after applying the regression shows that there is significant and positive relationship between all the variables used and $\mathrm{p}$ value of significance was less than 0.05 . The results are as were expected and the hypothesis $\mathrm{H} 1, \mathrm{H} 2, \mathrm{H} 3$ and $\mathrm{H} 4$ are accepted.

To explain the average data used in the research we applied the first step which was to do the descriptive analysis of the variable in the theoretical framework.

TABLE 1.

\begin{tabular}{|c|c|c|c|c|c|}
\hline & N & Minimum & Maximum & Mean & Std. Deviation \\
\hline L & $\mathbf{3 4 5}$ & $\mathbf{2 . 0 0}$ & $\mathbf{5 . 0 0}$ & $\mathbf{3 . 3 4 2 3}$ &. $\mathbf{5 3 8 3 3}$ \\
P & $\mathbf{3 4 5}$ & $\mathbf{2 . 0 0}$ & $\mathbf{5 . 0 0}$ & $\mathbf{3 . 8 3 6 7}$ &. $\mathbf{5 9 3 4 8}$ \\
T & $\mathbf{3 4 5}$ & $\mathbf{2 . 1 7}$ & $\mathbf{5 . 0 0}$ & $\mathbf{3 . 7 6 2 9}$ & $\mathbf{. 5 8 9 5 2}$ \\
L.S & $\mathbf{3 4 5}$ & $\mathbf{1 . 0 0}$ & $\mathbf{5 . 0 0}$ & $\mathbf{3 . 3 7 2 3}$ & $\mathbf{. 5 6 6 6 3}$ \\
E.P & $\mathbf{3 4 5}$ & $\mathbf{2 . 0 0}$ & $\mathbf{5 . 0 0}$ & $\mathbf{3 . 3 7 1 3}$ &. $\mathbf{5 6 6 7 3}$ \\
C.S & $\mathbf{3 4 5}$ & $\mathbf{2 . 0 0}$ & $\mathbf{5 . 0 0}$ & $\mathbf{3 . 3 4 2 6}$ & $\mathbf{. 5 4 3 7 5}$ \\
Valid N & $\mathbf{3 4 5}$ & & & & \\
\hline
\end{tabular}

The regression is run between all the variables in the theoretical framework. There are four facets of human capital investment (HCI), as learning/education (L), practice (p), training (T) and leadership style which are four main facets of capital human investment.

The human capital investment is also significantly related with the customer satisfaction and all the facets showing the constructive and significant relationship by having the $\mathrm{p}$ value less than 0.05 . this shows that $\mathrm{H} 1$ is accepted.

\section{Regression Analysis TABLE 2.}

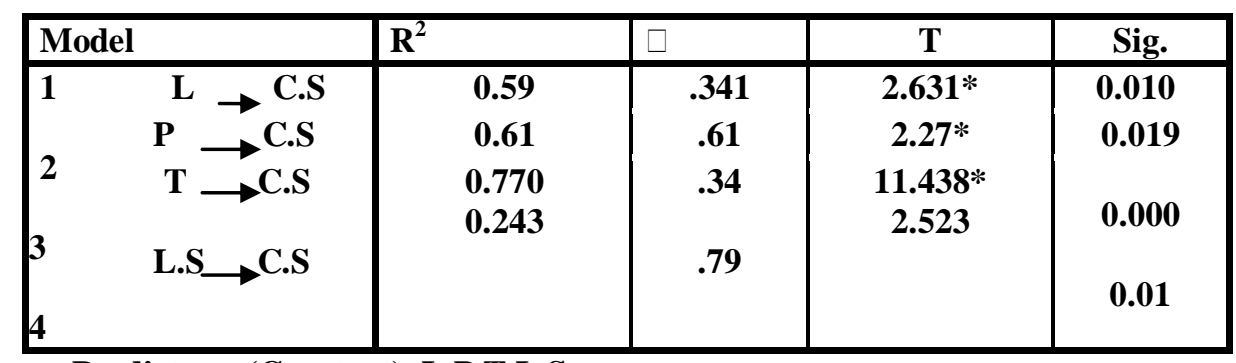

a. Predictors: (Constant), L,P,T,L.S 
The human capital investment facets and the employee performance were applied in the regression process. The human capital investment showing the significant relationship with the employee performance and $\mathrm{H} 2$ accepted. The learning has the significance level up to .01 while the other variables as learning/education $(\mathrm{L})$, practice $(\mathrm{p})$, training (T) and leadership style also has significance value of 0.01 . The positive and significant relationship between the variables shown that if the human capital investment is accurate then the employee performance will be high. Te learned employee performs better than others so do the practice and trained employees and good leadership style also give high performance.

Regression Analysis Table 3

\begin{tabular}{|c|c|c|c|c|c|}
\hline Model & & $\mathbf{R}^{2}$ & $\square$ & $\mathbf{T}$ & Sig. \\
\hline 1 & $\mathbf{L} \longrightarrow$ E.P & 0.30 & 0.174 & $2.027 *$ & 0.01 \\
\hline 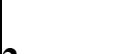 & $\mathbf{P} \longrightarrow$ E.P & 0.37 & 0.214 & $2.023 *$ & 0.01 \\
\hline 2 & $\mathbf{T} \longrightarrow \mathrm{E.P}$ & 0.60 & 0.567 & $2.563 *$ & \\
\hline 3 & L.S $\longrightarrow$ E.P & 0.460 & 0.462 & $2.765 *$ & $\begin{array}{c}0.01 \\
0.01\end{array}$ \\
\hline 4 & & & & & \\
\hline
\end{tabular}

a. Predictors: (Constant), L,P,T,L.S.

b. Dependent Variable: E.P

To verify the relationship between the E.P and the C.S regression results are given the $\mathrm{R}^{2} \quad 0.652$ with the significance level up to 0.01 , hence $\mathrm{H} 3$ accepted as shown by the results. The customer satisfaction will increase if the employee performance is better as the employees whose performance is better ultimately satisfied the customers.

Regression Analysis Table 4

\begin{tabular}{|l|l|l|l|l|}
\hline Model & $\mathrm{R}^{2}$ & $\square$ & $\mathrm{T}$ & Sig. \\
\hline $1 \quad$ E.P $\rightarrow$ C.S & .652 & .419 & $2.152 *$ & 0.01 \\
& & & & \\
\hline
\end{tabular}

\title{
a. Predictors: (Constant), E.P
}

b. Dependent Variable: C.S

Baron and Kenny (1986) who used the mediation by giving his rules for running the mediation, the required three conditions are fulfilled as there is significant relationship between the human capital investment and employee performance and the customer satisfaction. The significant relationship predicts the mediating role of employee performance between the human capital investment and the customer satisfaction shown in the table 5 which indicates the acceptance of $\mathrm{H} 4$.

Regression Analysis Table 5

\begin{tabular}{|l|r|r|r|r|r|}
\hline Model & $\square$ & \multirow{2}{*}{ R Square } & \multicolumn{3}{|c|}{ Change Statistics } \\
\cline { 4 - 6 } & & & $\begin{array}{l}\text { R Square } \\
\text { Change }\end{array}$ & F Change & Sig. F Change \\
\hline 1 & $\mathbf{0 . 1 9 3}$ & .571 & .211 & 33.512 & .000 \\
\hline
\end{tabular}

\author{
a. Predictors: (Constant), E.P \\ b. Predictors: (Constant), E.P, HCI
}

\section{Discussion}

The results of the research paper are significant and human capital investment is positively related with the customer satisfaction. While the employee performance is playing the role of mediation. The literature also supports the above results. The capital human investment is the intake of highly capable employees which have good performance level so the customer satisfaction will be achieved by the organization. The employee performance is high then customer will be satisfied and vice versa. The human capital investment is transferable so if the employee performance is high, he can get better option from the market and van switch to new job. Similarly capital human investment is the actual asset for the organization, because they are the one who ultimately interact with the customers either directly or indirectly and this interaction determines whether the customers are satisfied or not. 


\section{Limitation And Future Prospects}

There is problem in the genera of the results because the sample of the study only contains the cities of the Capital Islamabad and its adjacent Rawalpindi. The further research can be conducted by using the different methodologies and methods in addition by collecting data from the large sample size from different regions. This will lead to verify the results consistency and authentication of the results.

\section{Implication}

The results of this study show the relationship between the human capital investment and the customer satisfaction mediating the role of employee performance. The results are used to make the policies in the banking sector as well as other organizations to develop a relationship with the customers and utility enhance the profitability.

\section{References}

[1] Anderson, Eugene W. and Sanal K. Mazvancheryl (2004), "Customer Satisfaction and Shareholder Value," Journal of Marketing, 68 (October), 172-85.

[2] Anderson, Fornell, and Roland T. Rust (1997), "Customer Satisfaction, Productivity and Profitability: Differences Between Goods and Services," Marketing Science, $16 \quad$ (2), 129-45.

[3] Becker, Gary S. (1964), Human Capital. New York: Colombia University Press.

[4] Bolton, Ruth N. (1998), "A Dynamic Model of the Duration of the Customers's Relationship with a Continuous Service Provider: The Role of Satisfaction," Marketing Science, 17 (Winter), 45-65.

[5] Dess, G., and Shaw., (2001), "Voluntary Turnover, Social Capital, and Organizational Performance,"Academy of Management Review, 26 (3), 446-56.

[6] Fornell, Claes, Sunil Mithas, Forrest V. Morgeson III, and M.S. Krishnan (2006), "Customer Satisfaction and Stock Prices: High Returns, Low Risk," Journal of Marketing, 70 (January), 3-14.

[7] Harter, James K., Theodore L. Hayes, and Frank L. Schmidt (2002), "Business-Unit-Level Relationship Between Employee Satisfaction, Employee Engagement, and Business Outcomes: A Meta-Analysis,” Journal of Applied Psychology, 87 (2), 26879.

[8] Hartline, M., and Ferrell, O.C. (1996), "The Management of Customer-Contact Service Employees: An Empirical Investigation," Journal of Marketing, 60 (October), 52-70.

[9] Hitt, Michael, A., Bierman, Shimiuzu, K. and Kochhhar (2001), "Direct andModerating Effects of Human Capital on Strategy and Performance in Professional Service Firms: A Resource-Based Perspective," Academy of $\quad$ Management Journal, 44 (1), 13-28.

[10] Hudson, William (1993), Intellectual Capital: How to Build It, Enhance It, Use It. New York: John Wiley \& Sons.

[11] Jurgensen, Clifford (1978), "Job Preferences," Journal of Applied Psychology, 63 (3), 267-76.

[12] Luo, Xueming (2004), "Data Envelopment Analysis: A Management Science Tool for Scientific Marketing Research," Journal of Marketing Research, 42 (August), 113-16.

[13] Keiningham, Timothy L., Tiffany Perkins Munn, and Heather Evans (2003), "The Impact of Customer Satisfaction on ShareofWallet in a Business-to-Business $\quad$ Environment," Journal of Service Research, 6 (1), 37-50.

[14] Mittal, Vikas and Wagner Kamakura (2001), "Satisfaction, Repurchase Intent, and Repurchase Behavior: Investigating the Moderating Effect of Customer Characteristics," Journal of Marketing Research, 38 (February), 131-42.

[15] Mittal, Akin Sayrak, Pandu Tadikamalla, and Eugene W. Anderson (2005), "Dual Emphasis and the Long-Term Financial Impact of Customer Satisfaction," Marketing Science, 24 (4), 544-55.

[16] Oliva, Terence, Richard Oliver, and Ian MacMillan (1992), "A Catastrophe Model for Developing Service Satisfaction Strategies," Journal of Marketing, 56 (July), 83- 95.

[17] Oliver, R. L., (1980), "A Cognitive Model of the Antecedents and Consequences of Satisfaction Decisions," Journal of Marketing Research, 17 (November), 460-69.

[18] Ping, A.., (1993), "The Effects of Satisfaction and Structural Constraints on Retailer Exiting, Voice, Loyalty, Opportunism, and Neglect," Journal of Retailing, 69 (3), 320-52.

[19] Pugh, D. S., (2001), "Service with a Smile: Emotional Contagion in the Service Encounter," Academy of Management Journal, 44 (5), 1018-1027.

[20] Reichheld and W. Earl Sasser Jr. (1990), “Zero Defections: Quality Comes to Services,”Harvard Business Review, 68 (5), $105-111$.

[21] Rust, Katherine Lemon, and Valarie A. Zeithaml (2004), "Return on Marketing: UsingCustomer Equity to Focus Marketing Strategy," Journal of Marketing, 68 (January), 109-124.

[22] Rust, Roland T., Christine Moorman, and Peter R. Dickson (2002), "Getting Return on Quality: Revenue Expansion, Cost Reduction, or Both?" Journal of Marketing, 65 (October), 7-24.

[23] Ryan, A. Schmit, and Johnson, R., (1996), "Attitudes and Effectiveness: Examining Relations at an Organizational Level," Personnel Psychology, 49 (4), 853-82.

[24] Schlesinger, L., and Zornitsky,J., (1991), "Job Satisfaction, Service Capability, and Customer Satisfaction: An Examination of Linkages and Management Implications," Human Resource Planning, 14 (2), 141-49.

[25] Seiders, Kathleen, Glenn Voss, Dhruv Grewal, and Andrea Godfrey (2005), "Do SatisfiedCustomersBuyMore?Examining Moderating Influences in a Retailing Context," Journal of Marketing, 69 (October), 26-43.

[26] Szymanski, M. And Henard, D.H., (2001), "Customer Satisfaction: A Meta-Analysis of the Empirical Evidence," Journal of the Academy of Marketing Science, 29 (1), 16-35.

[27] Young, L., (2006), “The Helpful Index,” Business Week, (January 9), 92. 